\title{
Influence of distal ileum exclusion on hepatic and renal functions in presence of extrahepatic cholestasis
}

\author{
Influência da exclusão do íleo terminal nas funções hepáticas e renais em \\ presença de colestase extra-hepática
}

Evandro luis de Oliveira Costa'; Andy Petroianu, TCBC-Mg²; Geraldo Magela de Azevedo Júnior ${ }^{3}$

A B S T R A C T

\begin{abstract}
Objective: To verify whether the ileal exclusion interferes with liver and kidney functional changes secondary to extrahepatic cholestasis. Methods: We studied 24 rats, divided into three groups with eight individuals each: Group 1 (control), Group 2 (ligation of the hepatic duct combined with internal biliary drainage), and Group 3 (bile duct ligation combined with internal biliary drainage and exclusion of the terminal ileum). Animals in Group 1 (control) underwent sham laparotomy. The animals of groups 2 and 3 underwent ligation and section of the hepatic duct and were kept in cholestasis for four weeks. Next, they underwent an internal biliary bypass. In Group 3, besides the biliary-enteric bypass, we associated the exclusion of the last ten centimeters of the terminal ileum and carried out an ileocolic anastomosis. After four weeks of monitoring, blood was collected from all animals of the three groups for liver and kidney biochemical evaluation (albumin, ALT, AST, direct and indirect bilirubin, alkaline phosphatase, cGT, creatinine and urea). Results: there were increased values of ALT, AST, direct bilirubin, CGT, creatinine and urea in rats from Group 3 ( $p$ < 0.05). Conclusion: ileal exclusion worsened liver and kidney functions in the murine model of extrahepatic cholestasis, being disadvantageous as therapeutic procedure for cholestatic disorders.
\end{abstract}

Key words: Cholestasis. Liver fibrosis. Ileum/surgery. Liver/physiopathology. Rim/physiopathology.

\section{INTRODUCTION}

C holestatic diseases occur in all age groups, have limited therapeutic options and may progress to liver fibrosis and cirrhosis. Some of these diseases are accompanied by sometimes disabling extrahepatic serious manifestations, such as hepatic encephalopathy, pruritus, metabolic bone disease, amongst others ${ }^{1,2}$.

The etiological factors tend to be specific to each age group. The consequences of cholestasis and the mechanisms of liver injury, as well as the progression to fibrosis and liver cirrhosis, are related to the accumulation of bile acids in the liver. Clinical or surgical treatments that decrease biliary stasis delay or interrupt the progress of these diseases, improving symptoms and signs.

Hollands et al. ${ }^{3}$ proposed the exclusion of the last inches of the terminal ileum as a way to improve pruritus refractory to clinical treatment of children with progressive familial intrahepatic cholestasis (PFIC). This procedure reduced the rash and improved liver function biochemical laboratory values in the majority of patients. There was an improvement in liver histological appearance, observed in biopsies. However, there were few patients and the follow-up period was short ${ }^{4,5}$. Other authors studied this therapeutic approach, but the results were not in pediatric patients with cholestatic disorders such as PFIC.

Excluding this part of the terminal ileum aims to decrease the reabsorption of bile acids in the terminal ileum, increasing their fecal excretion, as well as decreasing their accumulation, both in the serum and in the liver. The objective of this study was to verify whether the exclusion or derivation of terminal ileum interferes with hepatic and renal changes caused by obstructive cholestasis.

\section{METHODS}

We studied 24 adult Wistar rats, weighing between $240 \mathrm{~g}$ and $320 \mathrm{~g}$, divided into the following groups $(n=8)$ : Group 1 - control; Group 2 - Ligation of the hepatic duct associated with internal biliary drainage; Group 3 Ligation of the hepatic duct associated with internal biliary drainage and exclusion of the terminal ileum.

All animals were placed in the vivarium of the Faculty of Medicine, UFMG, had free access to water and rat chow. After the care of asepsis and antisepsis, they were intramuscularly anaesthetized with a solution of $2 \%$

1. Clinics Hospital, Federal University of Minas Gerais - UFMG - and Odilon Behrens Hospital, Belo Horizonte, Minas Gerais State - MG, Brazil; 2. Department of Surgery, Faculty of Medicine, UFMG; 3. Betim Regional Hospital; Minas Gerais State Coroners Ofiice. 
xylazine and $10 \%$ ketamine at doses of $0.15 \mathrm{mg} / \mathrm{kg}$ and $0.25 \mathrm{mg} / \mathrm{kg}$, respectively.

The animals underwent abdominal trichotomy and were positioned in supine on a board with the legs attached by adhesive tape. We carried out disinfection with $70 \%$ alcohol. During operative procedures, respiratory and heart rates, respiratory movements and voluntary movements were observed. After completion of the operations, each animal was allocated in a ventilated place and observed until complete postanesthetic recovery.

Animals in Group 1 underwent laparotomy. The animals in groups 2 and 3 were subjected to laparotomy with double ligation of the common hepatic duct with 4-0 silk sutures, and its section between the ligatures (Figure 1A). After four weeks, all animals in Groups 2 and 3 were reoperated.

In Group 2, there was internal biliary drainage between the proximal stump of the bile duct and duodenum, with the aid of a $4 \mathrm{Fr}$. nelaton catheter measuring $4 \mathrm{~cm}$. One end of this catheter was connected to the bile duct and secured with 4-0 silk sutures and the other end was inserted into the duodenum and secured with purse-string suture using 5-0 polyglactin-910 (Figures 1B and 1C).

In Group 3, in addition to the biliary drainage performed in Group 2 we excluded ten $\mathrm{cm}$ of terminal ileum, as measured from the ileocecal papilla. The proximal segment of the ileum was anastomosed to the ascending colon in a single plane, with 50 polyglactin- 910 suture. The distal ileum was ligated with 4-0 silk suture (Figure 1D).

After eight weeks of the first procedure, all animals were subjected to relaparotomy, in which aspects of the liver and kidney were observed, as well as the patency of ileocolic and biliodigestive anastomosis; six milliliters of blood were collected from each animal after intracardiac puncture made by transdiaphragmatic route for biochemical analysis. The collected blood samples were placed in plastic tubes, protected from light and transported to the clinical laboratory. We measured alanine aminotransferase (ALT), aspartate aminotrasnferase (AST), albumin, direct and indirect bilirubins, alkaline phosphatase, gamma glutamyl transferase (ãGT), urea and creatinine. All laboratory tests were performed in the same apparatus.

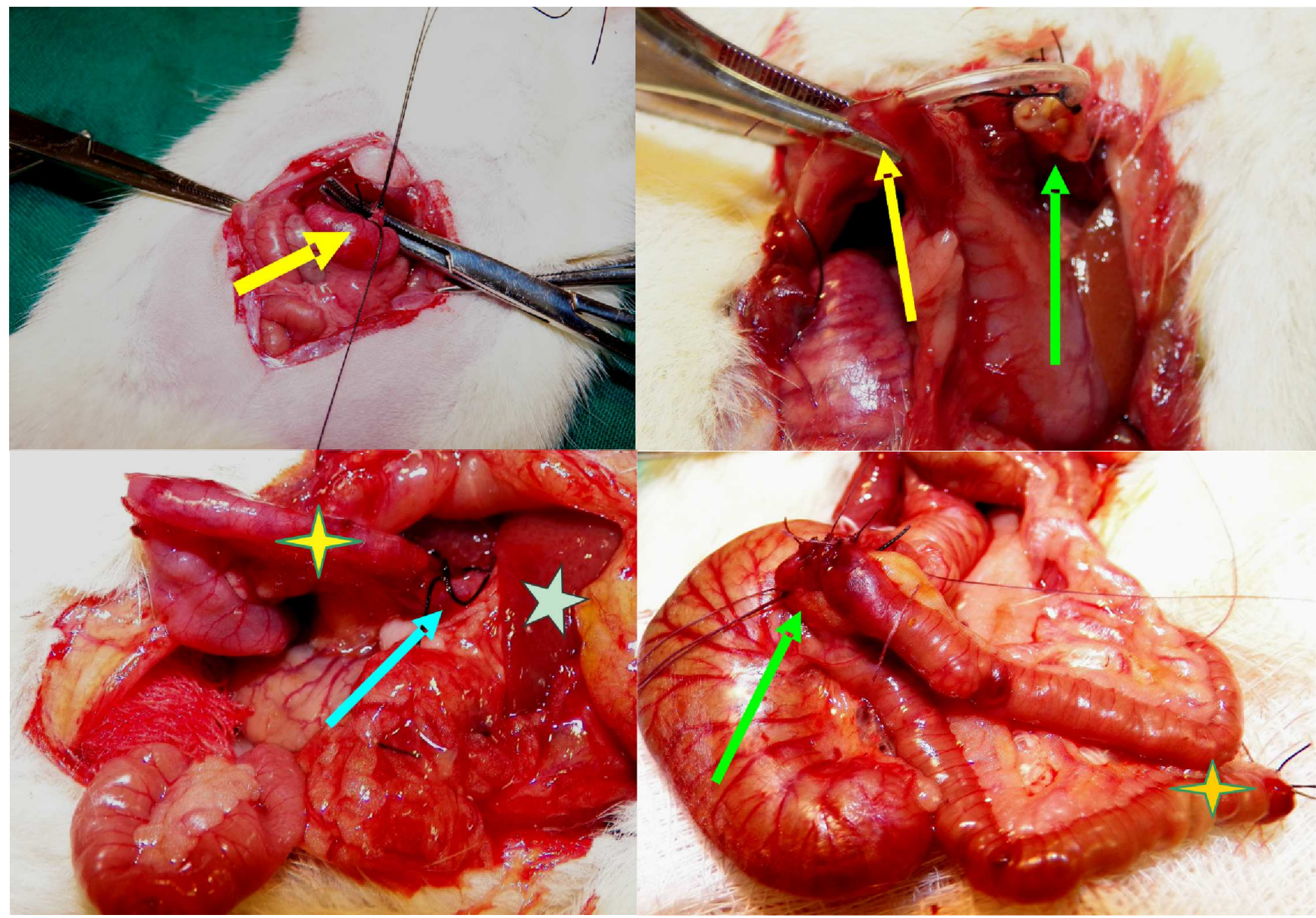

Figure 1 - Surgical aspects: A) Ligation of the hepatic duct; B) Making of the biliary-enteric anastomosis (positioning of the catheter in the hepatic duct (green arrow) and duodenum (yellow arrow); C) Final result of the biliary-enteric anastomosis (arrow). Duodenum (yellow star), liver (green star); D) ileocolic anastomosis (arrow). Segment of terminal ileum connected (star). 
The liver, kidneys and terminal ileum of all animals were removed for histological examination. The specimens biopsies were washed with tap water and fixed with $4 \%$ formaldehyde solution, then processed in routine pathological examinations.

Analysis of variance (ANOVA) and Kruskal-Wallis test were used for statistical analysis. The level of significance was the corresponding to $p<0.05$.

This study was approved by the Ethics on Animal Experimentation Committee (CETEA - UFMG), Protocol 041/2008 and by the Board of the Department of Surgery of the Faculty of Medicine of UFMG.

\section{RESULTS}

The control group (Group 1), showed no changes on macroscopic and optical microscopy. The kidneys and livers had normal appearance. All animals of groups 2 and 3 showed liver fibrosis in different stages. There was no liver cirrhosis in rats in this study. The kidneys of animals of groups 2 and 3 had no macroscopic or microscopic changes. In all animals of groups 2 and 3, the biliary-enteric bypass was patent. No signs of leaks or ischemia were observed in the ligated ileum, nor in the ileocolic anastomoses of rats from Group 3.

When comparing the renal biochemical tests of groups 1 and 2, no differences were observed. However, the hepatic function tests showed increased values of indirect bilirubin, $p=0.007$ (Table 1).

There was an increase in values of ALT ( $p=$ $0.0480)$, AST $(p=0.037)$, direct bilirubin $(p=0.032)$, ãGT $(p=0.010)$, creatinine $(p=0.003)$ and urea $(P=0.002)$ in Group 3 compared with control (Table 1).

The comparison of groups 2 and 3 yielded no differences in liver function tests, however there was an increase in serum creatinine $(p=0.007)$ and urea $(p=0.014)$ (Table 1).

\section{DISCUSSION}

This study evaluated the morphological and functional effects of excluding the terminal ileum in extrahepatic obstructive cholestasis. Changes in the absorption of bile acids in the terminal ileum in patients with ileal resection and ileitis point to the influence of the terminal ileum in the enterohepatic circulation of bile acids ${ }^{6}$, justifying the ileal exclusion as a treatment for cholestatic diseases $^{3}$.

Based on Hollands et al. ${ }^{3}$, Costa et al. ${ }^{7}$ used the experimental model of murine Kountouras et al. ${ }^{8}$ to compare the liver function tests and liver architecture in Wistar rats after ligation of the common hepatic duct ${ }^{7}$. In animals with the exclusion of the terminal ileum, the intensity of liver fibrosis was minor and values of indirect bilirubin and cGT were higher compared with the control'. However, this study could not explain the mechanisms by which ileal exclusion interfered with hepatic fibrosis. It is possible that this procedure decreases the absorption of excreted bile acids into the intestine, as proposed by Hollands et al. ${ }^{3}$. This hypothesis did not find support in the study of Costa et al. ${ }^{7}$, sine with ligation of the bile duct there was no more bile flow to the intestine, therefore no enterohepatic cycle, which justified the study of ileal exclusion after a biliodigestive derivation.

After ligation of the common hepatic duct, there is an increase in aminotransferases and canalicular enzymes in the first three weeks, which later decrease, indicating a tendency for liver failure, with decreased albumin ${ }^{9,10}$.

Several authors studied the effects of biliaryenteric bypass in liver function tests and liver architecture,

Table 1 - Mean and standard error of the mean liver and renal biochemical tests in groups 1, 2 and 3.

\begin{tabular}{|c|c|c|c|c|c|c|c|}
\hline \multirow[b]{2}{*}{ Albumin } & \multicolumn{2}{|c|}{ Group 1} & \multicolumn{2}{|c|}{ Group 2} & \multicolumn{3}{|c|}{ Group 3} \\
\hline & $2.26 \pm$ & 0.13 & $2.20 \pm$ & 0.29 & 2.12 & \pm & 0.24 \\
\hline ALT & $87.70 \pm$ & 6.3 & $91.14 \pm$ & 24.2 & 123.6 & \pm & 35.2 ** \\
\hline AST & $213.2 \pm$ & 68.1 & $210.1 \pm$ & 55.5 & 360.2 & \pm & 222.1 ** \\
\hline Direct bilirubin & $0.06 \pm$ & 0.04 & $0.05 \pm$ & 0.06 & 0.26 & \pm & $0.28 * *$ \\
\hline Indirect bilirubin & $0.05 \pm$ & 0.04 & $0.19 \pm$ & $0.11 *$ & 0.29 & \pm & 0.28 \\
\hline Alkaline Phosphatase & $434.7 \pm$ & 119.1 & $397.8 \pm$ & 165.8 & 392.8 & \pm & 196.1 \\
\hline "gt & $1.05 \pm$ & 0.62 & $2.55 \pm$ & 1.66 & 3.95 & \pm & $2.80 * *$ \\
\hline Creatinine & $0.4 \pm$ & 0.10 & $0.4 \pm$ & 0.12 & 0.65 & \pm & $011 * * *$ \\
\hline Urea & $41.75 \pm$ & 5.85 & $49.13 \pm$ & 9.7 & 92.90 & \pm & $51.2 * * *$ \\
\hline
\end{tabular}

ALT: alanine aminostransferase; AST: aspartate aminotransferase;

cGT: gamma glutamyl transferase; $p$ : $p$-value; *: $P<0.05$;

Group 1: Control;

Group 2: Ligation of the hepatic duct combined with internal biliary drainage;

Group 3: Ligation of the hepatic duct combined with internal biliary drainage and exclusion of the terminal ileum;

*: $p<0.05$ between groups 1 and 2;

$* *: p<0.05$ between groups 3 and 1 ;

***: $p<0.05$ between group 3 and groups 1 and between 2 and 3 . 
in periods of two to three weeks ${ }^{11-15}$. There was normalization of biochemical tests of liver function and decreased fibrosis severity after performance of the biliodigestive anastomosis ${ }^{11-15}$. Moreover, it was found that even after bile drainage, the animals persisted with hypoalbuminemia and abnormal hepatic architecture ${ }^{16,17}$.

There is no difference between the various options for biliary-enteric bypass for this experimental model ${ }^{13,14}$. In this study, we opted for a Roux-Y hepaticoduodenostomy using a nelaton prosthesis, which presented no technical difficulties or complications ${ }^{11,13,15}$. The internal biliary drainage is more efficient than the external one for the improvement in liver function and prevention of intestinal disorders secondary to the absence of intraluminal bile ${ }^{18,19}$.

Another advantage of this study was to maintain cholestasis for four weeks before biliodigestive derivation. This longer period of cholestasis enabled the development of liver fibrosis, allowing us to study the influence of biliary drainage on liver morphology and function, as well as observing a possible additional effect of the ileal exclusion. After biliary drainage there was normalization of liver function tests. In the group with ileal exclusion the values of direct bilirubin, AST, ALT and CGT worsened. With the data from this work, one may question the effectiveness of ileal exclusion as an adjunct in the treatment of cholestasis.
Kidneys and liver are the main excretory organs of the body. In a situation of cholestasis, there is increases renal excretion of products usually eliminated in the bile. This renal overload, with accumulation of harmful substances to the glomeruli, may be responsible for functional disorders of the kidney, which may progress to renal failure. This complication has been observed in the presence of hyperbilirubinemia and increased bile acids ${ }^{10,20}$.

Functional changes of the kidney are linked to etiological agents or hemodynamic changes, characteristic of chronic liver disease, in which there is peripheral vasodilation, renal vasoconstriction and activation of the renin-angiotensin system ${ }^{21-24}$. There is also increased oxidative stress and increased production of free radicals ${ }^{25,26}$, as well as nephrotoxicity caused directly and indirectly by bile acids and bilirubin, especially in situations of renal ischemia ${ }^{10,27-30}$.

In this study, animals undergoing biliary-enteric anastomosis and ileal exclusion showed elevated levels of urea and creatinine. Therefore, the ileal exclusion associated with biliary-enteric bypass did not reduce the renal disorder probably caused by the four weeks of cholestasis.

In conclusion, ileal exclusion associated with internal biliary bypass in an experimental murine model of bile duct ligation, for four weeks worsened liver and kidney functions.

\title{
R E S U M O
}

\begin{abstract}
Objetivo: verificar se a exclusão ileal interfere nas alterações funcionais hepáticas e renais, secundárias à colestase extra-hepática. Métodos: foram estudados 24 ratos, distribuídos em três grupos (n=8): Grupo 1 (controle), Grupo 2 (ligadura do ducto hepático combinada com drenagem biliar interna) e Grupo 3 (ligadura do ducto hepático combinada com drenagem biliar interna e exclusão do íleo terminal). Os animais do Grupo 1 (controle) foram submetidos a laparotomia e laparorrrafia. Os animais dos grupos 2 e 3 foram submetidos a ligadura e secção do ducto hepático e mantidos em colestase por oclusão biliar durante quatro semanas. $A$ seguir, foram submetidos a derivação biliar interna. No Grupo 3, associou-se a exclusão dos últimos dez centímetros do íleo terminal e anastomose ileocólica à derivação biliodigestiva. Após outras quatro semanas de acompanhamento, foi colhido sangue de todos os animais dos três grupos, para avaliação bioquímica do fígado e dos rins (albumina, ALT, AST, bilirrubinas direta e indireta, fosfatase alcalina, cGT, creatinina e ureia). Resultados: houve aumento dos valores de ALT, AST, bilirrubina direta, cGT, creatinina e ureia nos ratos do Grupo $3(p<0,05)$. Conclusão: no modelo murino de colestase extra-hepática, a exclusão ileal piorou as funções hepáticas e renais, sendo desvantajosa como proposta terapêutica para afecções colestáticas.
\end{abstract}

Descritores: Colestase. Fibrose hepática. íleo/operações. Fígado/fisiopatologia. Rim/fisiopatologia.

\section{REFERENCES}

1. Poupon R, Chazouillères O, Poupon RE. Chronic cholestatic diseases. J Hepatol. 2000;32(Suppl 1):129-40

2. Pusl T, Beuers U. Extrahepatic manifestations of cholestatic live diseases: pathogenesis and therapy. Clin Rev Allergy Immunol. 2005;28(2):147-57.

3. Hollands CM, Rivera-Pedrogo FJ, Gonzalez-Vallina R, Loret-deMola O, Nahmad M, Burnweit CA. Ileal exclusion for Byler's disease: an alternative surgical approach with promising early results for pruritus. J Pediatr Surg. 1998;33(2):220-4.

4. Kaliciñski PJ, Ismail H, Jankowska I, Kamiñski A, Pawlowska J, Drewniak $T$, et al. Surgical treatment of progressive familial intrahepatic cholestais: comparison of partial external biliary diversion and ileal bypass. Eur J Pediatr Surg, 2003;13(5):307-11.

5. Davis AR, Rosenthal P, Newman TB. Nontransplant surgical interventions in progressive familial intrahepatic cholestasis. J Pediatr Surg. 2009;44(4):821-7

6. Hofmann AF. Inappropriate ileal conservation of bile acids in cholestatic liver disease: homeostasis gone awry. Gut. 2003;52(9):1239-41.

7. Costa ELO, Azevedo Jr GM, Petroianu A. Efeito da ressecção do íleo terminal na fibrose hepática secundária à ligadura do ducto hepático comum em ratas. Rev Col Bras Cir. 2006;33(1):19-23

8. Kountouras J, Billing BH, Scheuer PJ. Prolonged bile duct obstruction: a new experimental model for cirrhosis in the rat. Br J Exp Pathol. 1984;65(3):305-11 
9. Hinz S, Franke H, Machnik G, Müller A, Dargel R. Histological and biochemical changes induced by total bile duct ligation in the rat. Exp Toxicol Pathol. 1997;49(3-4):281-8.

10. Israeli BA, Bogin E. Biochemical changes in liver, kidney and blood associated with common bile duct ligation. Clin Chim Acta. 1986;160(2):211-21.

11. Ryan CJ, Than T, Blumgart LH. Choledochoduodenostomy in the rat with obstructive jaundice. J Surg Res. 1977;23(5):321-31.

12. Abdel-Aziz G, Lebeau G, Rescan PY, Clément B, Rissel M, Deugnier $Y$, et al. Reversibility of hepatic fibrosis in experimentally induced cholestasis in rat. Am J Pathol. 1990;137(6):1333-42.

13. Zimmermann $H$, Reichen J, Zimmermann A, Sägesser $H$, Thenisch $B$, Höflin F. Reversibility of secondary biliary fibrosis by biliodigestive anastomosis in the rat. Gastroenterology. 1992;103(2):579-89.

14. Jalink D, Urbanski SJ, Lee SS. Bilioenteric anastomosis reverses hyperkinetic circulation in bile duct-ligated cirrhotic rats. J Hepatol. 1996;25(6):924-31.

15. Li W, Chung SC. An improved rat model of obstructive jaundice and its reversal by internal and external drainage. J Surg Res. 2001;101(1):4-15.

16. Younes RN, Vydelingum NA, Derooij P, Scofnamiglio F, Andrade L, Posner $\mathrm{MC}$, et al. Metabolic alterations in obstructive jaundice: effect of duration of jaundice and bile-duct decompression. HPB Surg. 1991;5(1):35-48.

17. Marinelli Ibarreta A, Sánches Movilla A, Izquierdo F, Burgos Lázaro F, Arce Alvarez A, del Castillo-Olivares Ramos JL. Cambios morfopatológicos pre y postderivación biliodigestiva en cirrosis experimental por ligadura de via biliar en rata. Rev Esp Enferm Dig. 1995;87(1):25-31.

18. Clements WD, Parks R, Erwin P, Halliday MI, Barr J, Rowlands BJ. Role of the gut in the pathophysiology of extrahepatic biliary obstruction. Gut. 1996;39(4):587-93.

19. Ding JW, Andersson R, Soltesz V, Willén R, Loft S, Poulsen HE, et al. The effect of biliary decompression on bacterial translocation in jaundice rats. HPB Surg. 1993;7(2):99-110.

20. Gentilini P, La Villa G. Liver-kidney pathophysiological interrelationships in liver diseases. Dig Liver Dis. 2008;40(12):90919.

21. Rodrigo R, Avalos N, Orellana M, Bosco C, Thielemann L. Renal effects of experimental obstructive jaundice: morphological and functional assessment. Arch Med Res. 1999;30(4):275-85.
22. Perreira RM, dos Santos RA, Oliveira EA, Leite VH, Dias FL, Rezende AS, et al. Development of hepatorenal syndrome in bile duct ligated rats. World J Gastroenterol. 2008;14(28):4505-11.

23. Fogarty BJ, Parks RW, Rowlands BJ, Diamond T. Renal dysfunction in obstructive jaundice. Br J Surg. 1995;82(7):877-84.

24. Betjes MG, Bajema I. The pathology of jaundice-related renal insufficiency: cholemic nephrosis revisited. J Nephrol. 2006;19(2):229-33.

25. Bomzon A, Holt S, Moore K. Bile acids, oxidative stress, and renal function in biliary obstruction. Semin Nephrol. 1997;17(6):549-62.

26. Panozzo MP, Basso D, Balint L, Zaninitto M, Bonvicini P, Plebani M. Renal functional alterations in extrahepatic cholestasis: can oxidative stress be involved? Eur Surg Res. 1995;27(5):332-9.

27. Torres AM. Renal elimination of organic anions in cholestaisis. World J Gastroenterol. 2008;14(43):6616-21.

28. Call NB, Tisher CC. The urinary concentrating defect in Gunn strain of rat. Role of bilirubin. J Clin Invest. 1975;55(2):319-29.

29. Kaler B, Karram T, Morgan WA, Bach PH, Yousef IM, Bomzon A. Are bile acids involved in the renal dysfunction of obstructive jaundice? An experimental study in bile duct ligated rats. Ren Fail. 2004;26(5):507-16.

30. Ackerman Z, Karmeli F, Pizov G, Ben-Dov I, Pappo O. Renal effects of gentamicin in chronic bile duct ligated rats. Dig Dis Sci. 2006;51(2):406-15.

Received on $18 / 12 / 2012$

Accepted for publication 20/02/2013

Conflict of interest: none.

Source of funding: none.

How to cite this article:

Costa ELO, Petroianu A, Azevedo Júnior GM. Influence of distal ileum exclusion on hepatic and renal functions in presence of extrahepatic cholestasis. Rev Col Bras Cir. [periódico na Internet] 2014;41(2). Disponível em URL: http://www.scielo.br/rcbc

Address for correspondence:

Andy Petroianu

E-mail: petroian@medicina.ufmg.br / petroian@gmail.com 